Noman 2019, 37(2), 83-92

Revista de Psicologia, Ciències de l'Eduació i de l'Esport

ISSN: 1138-3194

CFacultat de Psicologia, Ciències de l'Educació i de l’Esport Blanquerna

Universitat Ramon Llull

(c) (1) (2)

\title{
Escaping from the English classroom. Who will get out first?
}

\author{
Alexandra Santamaría \& Elena Alcalde \\ Universidad de Alcalá
}

Received: 2019-3-8

Accepted: 2019-10-1

\section{Escaping from the English classroom. Who will get out first?}

Summary. The aim of this study is to present an innovative teaching proposal implemented in the English classroom in a Translation Degree that can be replicated in other disciplines, and to analyse the potential for an activity like this one to have a very positive effect on the way students engage with and learn a second language. The study was based on the hypothesis that the use of an escape room, chosen here from a range of possible gamified activities, could enhance students' motivation to learn a second language and serve as an enjoyable and cooperative way to help them develop oral and writing skills. This paper opens with a review of relevant research in the field of English language learning and analyses the potential benefits of introducing gamification techniques to the classroom. The next section details the method used in the study, including information about the instrument, the participants and the academic context. The activity implemented is also described. After that, the results of the study are presented and illustrated with examples from the data. Finally, some implications of the study are discussed.

Keywords: escape room; gamification; learning; innovation

Escapar de la clase de inglés. ¿Quién será el primero?

Resumen. El objetivo de este estudio es presentar una propuesta de enseñanza innovadora implementada en el aula de inglés en un Grado de Traducción que pueda replicarse en otras disciplinas, y analizar el potencial que una actividad como esta puede tener a la hora de motivar y fomentar la participación de los estudiantes en el aprendizaje de un segundo idioma. El estudio se basó en la hipótesis de que el uso de un escape room como actividad gamificada podría aumentar la motivación de los estudiantes para aprender un segundo idioma y servir como una forma agradable y cooperativa para ayudarlos a desarrollar destrezas orales y escritas en inglés. En primer lugar, aportaremos una revisión teórica en la que se argumentarán las ventajas de introducir técnicas de gamificación en el aula. Posteriormente detallaremos el método utilizado en el estudio e incluiremos información sobre el instrumento, los participantes y el contexto académico. Del mismo modo, explicaremos la actividad desarrollada y los resultados obtenidos del estudio, que ilustremos con distintos ejemplos. Finalmente, concluiremos con algunas de las implicaciones estudio.

Keywords: escape room; gamificación; aprendizaje; motivación 


\section{Introduction}

Today's students are digital natives (Prensky, 2001) who demand require new and innovative methodologies in many areas of life. Gisbert \& Esteve (2011) describe this generation as having a marked digital literacy and a constant need to be connected. Unlike earlier generations, they grew up with digital technology, and they feel comfortable with multi-tasking, rely on graphics for communication and thrive on instant gratification and rewards (Akçayır, Dündar, \& Akçayır, 2016).

Meanwhile, many teachers are members of prior generations that Prensky (2001: 1) called "digital immigrants", referring to educators who "were not born into the digital world", but have adopted and use many aspects of new technology. It is crucial for educators to offer today's students state-of-the-art approaches that attract their attention and connect with their everyday lives. Gamification is one of these emerging techniques, and it shows no signs of stopping (Kapp, 2012). Although it is mainly used in business contexts, "the penetration of the gamification trend in educational settings seems to be still climbing up to the top" (Dicheva et. al, 2016: 2). Teachers, professors and educational professionals in general have the opportunity to create new, challenging, meaningful and interactive learning experiences for today's students. Boredom, lack of attention and loss of interest tend to contribute "adversely towards student engagement, learning and overall performance across a diverse range of settings including universities" (Sharp et al., 2017, p. 2).

Previous studies have shown that learning and motivation in the classroom can be enhanced through education games, which has made what is known as "gamification" increasingly popular (Feng \& Chen, 2013). Teachers focus on getting through to students, using a range of means to achieve this. The inclusion of gamified experiences in an English classroom within a Translation degree could thus serve as an example to be adapted to any higher education class, for the purposes of engaging students and achieving improvements in the way they learn and retain information.

The main aim of this study is to present an innovative teaching proposal implemented in an English classroom within a Translation Degree, with the expectation that it can be replicated in other disciplines. Secondly, the study will analyse how a proposal like this one could have a positive effect on how students, even at the university level, engage with and learn a second language. Our study was based on the hypothesis that the inclusion of an escape room, chosen from among the range of gamified activities, could enhance students' motivation to learn a second language, and serve as an enjoyable and cooperative way to help them develop oral and writing skills. The study will seek to answer the following three research questions:

Research question 1: What are students' perceptions of what during a gamified experience and how they learn it?
Research question 2: Will the use of a gamified experience enhance students' motivation in a second language classroom within a Translation Degree?

Research question 3: Will students express a preference for the use of a gamified experience be over traditional methodologies?

Many studies have demonstrated the positive effects of the inclusion of gamified experiences in the English as a Foreign Language classroom (Figueroa Flores, 2015; New Media Consortium Report, 2014). However, no research has been published on the inclusion of such innovative methodologies in Translation Degree subjects, which reveals the importance of this research and the need to seek out new methodologies to use in degrees that emphasise not only language, but also professional competences for the students' future careers.

This paper opens with a review of relevant research in the field of English language learning and analyses the potential benefits of introducing gamification techniques to the classroom. Next, the method is presented, including information about the instrument, the participants and the academic context. The activity implemented is also described. After that, the results of the study are presented and illustrated with examples from the data. Finally, the implications of the study are discussed.

\section{Literature review}

\section{To play or to gamify?}

When talking about the notion of play in general, we are referring to a broad, loosely defined idea of having fun (Deterding et al., 2011), but when we talk more specifically about gamification, we mean the use of activities featuring elements of a game with the intention of improving participants' retention (Faiella \& Ricciardi, 2015). Playing, in the words of the MerriamWebster Dictionary (2018), is a "recreational activity", as opposed to what several authors (Perrotta et al., 2013; Simões et al., 2013; De Sousa Borges et al., 2014) have agreed to call "gamification", which is an approach that uses characteristics of game-like activities in nongame settings.

The term was coined in 2002 (Marczewski, 2012), but it was not until the second half of the year 2010 (Deterding et al., 2011) that it came into more frequent use in classroom environments to describe teachinglearning experiences. It is not the only term that has appeared to make reference to this methodology, since parallel terms like "productivity games" (McDonald, 2008), "surveillance entertainment" (Grace, 2008), "funware" (Takahashi, 2008), "playful design" (Ferrara, 2012) or "behavioral games" (Dignan, 2011) have also emerged in this field of study. However, "gamification" is the most widely used term, although the term has been defined in a number of ways. For example, it has been used to talk about the way the use of computer and video games has permeated everyday life (Dimitrios \& Niemann, 2017). Here, though, the word is used 
to refer to the use of game-based activities in the classroom to maintain the attention and increase the motivation of the students to achieve specific objectives and outcomes. Kapp (2012) defined the use of gamebased mechanics as engaging and motivational, while pointing out their potential to promote problemsolving skills and learning. A number of scholars have studied and attempted to define the term, but Kiryakova et al. (2014: 1) summarized the concept as "an integration of game elements and thinking in activities that are not games". These authors also listed six features that play an important role in this methodology: (1) users, (2) challenges/tasks, (3) points, (4) levels, (5) badges and (6) ranking of users. Furthermore, Ružić and Dumančić (2014: 199) refer to another important characteristic of gamification called "game foundation". They define it as the element that motivates the student "to get interested in the challenge defined by the rules, interactivity and feedback which are shown as emotional reactions within the quantitative result".

In light of the research described above, we can conclude that gamification includes some features of play, but the two terms are not synonymous. While playing refers to the broader concept of activities that involve recreation, gamification entails, to a greater or lesser extent, the inclusion of game-related activities to achieve a given objective, generally speaking, to learn.

\section{Gamification and technology in the EFL classroom}

Learning a second language has become one of the most important requirements for today's generations to get by in both social and work contexts. The development of new methodologies to engage second language learners has attracted the attention of a number of scholars, and the inclusion of gamification is one of the most significant new approaches, due to the importance of new technologies to our digital native students.

The issue of gam-based language learning (GBLL) has attracted a great deal of scholarly interest in recent years, with researchers examining these techniques in contexts ranging from K-12 students to the university level (Kapp, 2012). Recent examples in the literature show that GBLL can enhance communicative skills and student engagement (York \& William, 2018). Haskell (2013) described the experience of implementing questbased learning and game mechanics in a French university class as motivating, meaningful and persistent. The author highlighted that the improvement in the students' had gone beyond that of the equivalent traditional course.

The inclusion of games in the EFL classroom brings with it improved participation, cooperation, creativity and results. The immediate feedback that students obtain thanks to this resource has a direct effect on the learning outcomes and motivation. Students feel incentivized by meeting certain challenges and, as a consequence, the level of interest in the activity in- creases, leading to an optimal learning experience. Foncubierta y Rodríguez (2014) describe the inclusion of gamification in a second language learning environment as a resource that contributes to the development of positive attitudes among students, reflected in improvements in the following areas:

- Cooperation

- Experiential learning

- Self-image and motivation

- Competitiveness as a motivation tool

- Autonomy

- Error tolerance

Thanks to application designers and the software industry, the number of tools to boost the motivation and digital competence of second language learners has mushroomed in recent years. Students have at their disposal what is "unquestionably one of the most inventive, fast-moving, complex media enterprises currently in existence" (Thorne \& Watters, 2013, p. 49), and we as teachers should take advantage of the situation and deploy a range of technological resources in the EFL classroom. There is a constant stream of new mobile-applications for second language learning. Moreno, Leiva \& Matas (2016) published a taxonomy of these apps, based on highly ludic approaches, gamified techniques and challenges and appealing rewards. These features allow for the development of enriched, flexible, interactive, dynamic and attractive learning environments. Furthermore, these didactic electronic tools can be adapted to different levels of learning and varied linguistic competences, and, what's more, they can be used anywhere, anytime. These authors list apps like Duolingo, Wlingua, Busuu, Vocabla, Lingualia, Funland, Bitstrips, among many others.

In order to meet the needs, demands, requirements and challenges of our current education system, it is a priority for teachers to include game-based activities which foster the development of oral and written skills in our $21^{\text {st }}$ century students. However, we should always bear in mind the need to implement them as part of a broader pedagogical approach, one that employs new methodologies to facilitate the tasks of all the participants in the education process (Cebrián, 2011; Martínez \& Sánchez, 2011).

\section{Learning a foreign language in a Translation Degree. What do students need to know?}

The use of translation in the general foreign language classroom has been traditionally limited to literary and scientific texts. The inclusion of translation in the language classroom is seen by a wide number of researchers as beneficial (González Daviès, 2004; Malmkjaer, 2004). However, not much has been said about the lack of specialisation of English classes in Translation Degrees. At this point, it is important to establish a distinction between what is called Translation for Other Learning Contexts (TOLC) and "translation to acquire professional translator competence" (González 
Daviès, 2004, 2018; Hubscher-Davidson \& Borodo, 2012 , p.163), which is the main issue in this paper. The former refers to the acquisition of linguistic skills and intercultural competence, whereas the latter places emphasises the acquisition of translation competences. All in all, the main difference between these two concepts is their purpose.

We believe that by introducing preliminary translation activities in an English classroom within a Translation Degree, and by focusing more on the acquisition of professional translation competences than on general linguistic skills (as TOLC studies would do), we can help students become aware of the importance of using the right terms and grammatical structures and thus of the difficulties tied to the translation process. Moreover, as the authors concluded in a previous study (Alcalde \& Santamaría, 2018), the inclusion of this type of exercises in the second language classroom within a Translation Degree triggers students' interest in the profession. Going beyond the use of conventional second language learning activities like reading, listening and writing, (while not neglecting them completely) will thus result in more meaningful learning experiences, influencing how students learn and, more importantly, how teachers teach.

Students in a Translation and Modern Languages Degree need to learn everything from the basic to the more complex grammar and vocabulary features of the second language, in this case English, as they will be future language specialists and will translate texts from this language into their mother tongue. Their future career demands they acquire a good command of the language in various registers and in all four skills. Teachers' performance, then, should cater to these needs and demands, bearing in mind the characteristics of their digitally immersed students. Therefore, students learning a second language in a Translation Degree should be motivated via inspirational, meaningful, autonomous, appealing and cognitively demanding activities that allow them to escape the boredom of traditional methodologies and awaken their interest in honing their main future tool of work: the English language. The authors of this study were optimistic that the use of an escape room in the classroom would be an effective way to achieve the beneficial results promised by this type of activity. In order to demonstrate the effectiveness of this tool, we herein present the results obtained via its implementation.

\section{Method}

\section{Definition of escape room}

An escape room is a real-life team-based puzzle game where people are locked in a room and have to solve puzzles together to get out (Chen, 2015). Some common elements of this game are that it is team-based, has a clear objective and is themed under a story. In Spain, the number of companies offering the gaming experience of the escape room is ever increasing (Rizzo, 2018), since it has become a very popular free time activity.

Much like other learning games described by York and William (2018), escape rooms can be beneficial in the classroom in that they provide learners with sharedgoal orientation. Instead of making players compete, escape room games reduce their cognitive load and promote interaction in a social and collaborative learning environment. Moreover, playing these games is a social experience which provides students with meaningful interaction in the foreign language, and this interaction can be nurtured by their classmates and professor.

Regarding motivation, the incorporation of games into education is often considered more effective than traditional teaching methods in enhancing learning motivation, active participation and concentration among students (Feng and Chen, 2013, p. 1045). In order to better motivate our students, we must let them know that their opinions matter. Contemporary students demand the opportunity to follow their interests and passions, to create new things making use of all the tools that surround them, to work as a team, to make decisions and share control, and to both cooperate and compete (Prensky, 2005). Gamification is a way to cater to many of these wishes on the part of students, but as pointed by Castellón \& Jaramillo (2012), in order for these techniques to be effective the demands of the challenges presented to the students must be proportional to their competences to carry them out successfully. The more complicated the challenges are, the greater the likelihood that our escape room, will be stressful and difficult to solve. On the other hand, if the challenges are very easy, students will be bored by them. The result of either overly complicated or excessively easy activities will be a lack of motivation and consequently a loss of interest. To avoid this situation, the design of the gamified activity should consist of three distinct steps: (1) the creation of the game, (2) the modification of the game and (3) the analysis of the game (Salen \& Zimmerman, 2004).

\section{Instrument}

A questionnaire with open and closed questions was adapted from a previous study on GBLL (York \& William, 2018) to evaluate the degree to which students accepted this game. Questions included items related to what skills they had used the most, if they thought the activity was an effective way to learn English and their perception of the game. We were aware of the limitations of the survey, but we considered it a valid instrument to test the hypothesis of our study and answer our research questions. The questionnaire was also validated by three experts from our university. It was distributed in printed form in class by the teachers to ensure the participation of all students that took part in the game (only two of them were missing on 
the day the activity was conducted, so a total number of 22 students participated). It was anonymous and students were asked to give their consent to the use of the results of the survey for research purposes. The descriptive statistical data from the survey was also triangulated with qualitative information obtained from the open questions.

\section{Academic Context}

This teaching proposal was part of the English 2 course within the Degree in Translation and Modern Languages of the University of Alcalá (Spain). This is a compulsory course taught in the second semester of the first academic year of the degree and, as indicated in the syllabus, it is designed to give students grammar, oral and written skills to help them master their studies in English. In addition, students are expected to achieve greater independence in their language learning with a view toward lifelong learning as English language specialists. At the end of the course, students must have reached a B2.2 level or higher, according to the Common European Framework (Syllabus of the English II course, 2017).

\section{Description of the Activity}

When designing the game described in this study, we followed the seven design principles proposed by Liu (2011), which Feng and Chen also applied in their game-based study (2013):

- Analyse the traits of the learners and understand their prior knowledge.

- Establish clear teaching objectives and select appropriate gaming equipment.

- Combine the teaching objectives with the game content.

- Remember that teaching is the primary goal and that the game is a supplementary tool.

- Take advantage of game characteristics to arouse student interest.

- Enable students to enjoy themselves while they take control of learning.

- Periodically assess learning effectiveness and improve teaching.

This activity was carried out two weeks before the end of the semester, having been planned following a review of contents taught in previous classes. Students were required to solve seven different challenges. Findings suggest that providing clear objectives, challenges and continuous feedback throughout the game in an environment of friendly competition and cooperation among students contributes to achieving what Huang and Yeh (2017) have called a "meaningful gamification experience". Before the game started, students were divided into five different teams (22 students in total). Students were already familiar with the concept of the escape room due to its popularity in the country, but the professor explained all the different parts of the game. They were warned that they could only speak in English or they would be giving a warning (pink card), and that the second warning (red card) would entail their disqualification from the game. They had to choose a leader who would interact with the professor to submit the answers to the challenges for correction and obtain instructions from the professor. The seven challenges in the game are explained below.

\section{Challenge 1: Grammar activity}

Students opened an envelope with the three different parts of the first activity. This activity was adapted from the general textbook of the course (MacMillan, 2016). As they finished each part, they had it checked by the professor, and if everything was correct, they would get one letter. They needed to have all three parts correct in order to get the three letters of the code for the next challenge.

Part 1:

Instructions: Rewrite the sentence so that it has a similar meaning and includes the word or phrase in brackets. (Letter for the code: A)

From the way he acts, he thinks he's the boss. (as if) Possible answer: He acts as if he was the boss. Possible answer: He acts as if he were the boss.

We forgot the map - which was a mistake. (if only) Answer: If only we hadn't forgotten the map.

I think you should go home now. (time)

Answer: It's time you went home now.

\section{Part 2:}

Instructions: Write the plural of these words. If there is no plural, leave it blank. If there is only a plural form, write P. (Letter for the code: C)

Tomato: Tomatoes

Crisis: Crises

Deer -

Sheep -

Clothes: P

Kilo: Kilos

Part 3:

Instructions: Complete the sentence by putting the verb in brackets into the singular or plural. Write both when possible. (Letter for the code: E)

Billiards is (be) a popular game in many countries.

Each member of the team receives (receive) the same payment for the match.

The news is (be) on Channel Five at half past nine. None of these restaurants is / are (be) any good, I'm afraid.

There is (be) a new series of Madmen on Channel Six. Economics is (be) boring.

The code for the next challenge was ACE. 


\section{Challenge 2: Reading comprehension}

Once students had the code for this challenge, the professor sent an email to the leader with an encrypted .pdf document.

'pdflocked.pdf' está protegido. Escriba una Contraseña de apertura de documento. Escribir contraseña: Aceptar Cancelar

Figure 1. Encrypted .pdf document.

Instructions: Put the different paragraphs in the right order and write the corresponding number in the box. Once you have the numbers in the right order, you need to substract the first pair of numbers and the second pair of numbers, for example 58-14.

Table 1. Right order of paragraphs

\begin{tabular}{l}
\hline Paragraph number \\
\hline 2 \\
\hline 4 \\
\hline 3 \\
\hline
\end{tabular}

The text that was chosen for this activity was adapted from Kasa (2018) and it is shown below with an altered order of paragraphs as students saw them in the document:

1. Experts have connected stress with blood sugar and belly fat. Chronic stress raises insulin, driving relentless metabolic dysfunction that becomes weight gain, insulin resistance and ultimately diabetes.

2. Chronic stress has become epidemic in our society, where faster seems better and we pack more obligations into our ever-expanding schedules.

3. Insulin isn't the only hormone that becomes out of balance with stress. Your adrenal glands release hormones like adrenaline and cortisol that flood your system, raising your heart rate, increasing your blood pressure, making your blood more likely to clot, damaging your brain's memory center, increasing belly fat storage, and generally doing damage to your body.

4. Research has confirmed the havoc stress can wreak, with one meta-analysis involving 300 studies finding that chronic stress could damage immunity. Another study found stressed-out women had significantly higher waist circumference compared to non-stressed women.

The result that they got was 11 , which the code that they needed for the next challenge.

\section{Challenge 3: Translation}

Students had to take one of the books in the room and open it to the page corresponding to the number that they had been given in the previous challenge. On that page, they found a paragraph that they needed to translate. The books covered different topics such as economics and politics, but the paragraphs chosen for translation had been assessed by the professor so that they would be of similar degrees of difficulty. Once they had finished the translation and had it checked by the professor, they were given the code for the next encrypted document.

\section{Challenge 3: Listening comprehension}

The code for the next challenge gave access to a document with listening comprehension activities for Dua Lipa's song IDGAF.

Part 1: Can you find two idiomatic phrases in the lyrics of the song?

I wasn't born yesterday.

You made your bed sleep in it.

Part 2: Can you find an expression using "get + past participle"?

Get gone

Part 3: What is the word that follows these verbs?

Your time is up

I care about you

You blamed it all on the alcohol.

I see you begging on your knees.

Get up off your knees.

You keep reminiscing on when you were my man.

I'm over you.

If they got the answers correct, they were given the code for the next encrypted document.

\section{Challenge 4: Writing / Translation}

Instructions: Read the text and complete the activities that appear below.

This year is shaping up to be a bumper year for retail. America had its biggest online shopping day ever on Cyber Monday with $\$ 3.39$ billion in sales. Shoppers are bombarded by tricks worthy of a magician when they walk into a store and, some at least, are growing wise to them.

To avoid overspending, there are some rules of what not to do, says marketing consultant Martin Lindstrom, author of the book "Brandwashed: Tricks Companies Use to Manipulate Our Minds and Persuade Us to Buy."

Rule No. 1: "Don't bring your kids with you," he says. They'll help you spend 29\% more than your budget, according to a study of nearly 3,000 consumers Lindstrom carried out.

No. 2: "Don't shop with your partner," he says. He or she will make you spend 19\% more than planned.

No. 3: "Don't use a shopping cart. People who carry their stuff spend 8\% less."

No. 4: Carry $\$ 100$ bills. "People are far less likely to want to break bigger notes," he says.

(Text adapted from MarketWatch) 
Part 1: Create rule no. 5.

Part 2: Translate the following figures (you might need to check Spanish linguistic such as Diccionario Panhispánico de Dudas, Fundéu or Ortografía de la RAE).

Table 2. Translation activity

\begin{tabular}{ll}
\hline English & Spanish \\
\hline$\$ 3.39$ billion & 3,39 mil millones $\$$ \\
\hline 3,000 consumers & 3000 consumidores \\
\hline $8 \%$ less & un $8 \%$ menos \\
\hline
\end{tabular}

Challenge 5: Vocabulary

Students were given an envelope with the following vocabulary activity extracted from the textbook cited earlier. The letters in the right order were the code to the final encrypted document.

Instructions: Read the sentences and match them with the type of movement they describe. The right order of letters will be your code for the final challenge (befdgca).

Table 3. Activity from the 5 th challenge

\begin{tabular}{ll}
$\begin{array}{l}\text { 1. He heard a crash behind him and } \\
\text { span round to see what it was. }\end{array}$ & a. Move from side to side. \\
\hline $\begin{array}{l}\text { 2. Another wave of passengers } \\
\text { poured out into the arrivals hall. }\end{array}$ & $\begin{array}{l}\text { b. Turn quickly to face the opposite } \\
\text { direction. }\end{array}$ \\
$\begin{array}{l}\text { 3. A young woman rushed down the } \\
\text { stairs to the platform just as the } \\
\text { train pulled out. }\end{array}$ & $\begin{array}{l}\text { c. Hit something hard, causing } \\
\text { damage. }\end{array}$ \\
$\begin{array}{ll}\text { 4. The narrow stairs spiraled up to } \\
\text { the top of the tower. }\end{array}$ & $\begin{array}{l}\text { d. Go round and up in repeated } \\
\text { circles. }\end{array}$ \\
$\begin{array}{l}\text { 5. She apologized as her case } \\
\text { bumped against another passenger's } \\
\text { leg. }\end{array}$ & e. A lot of people moving together. \\
$\begin{array}{l}\text { 6. A bus had collided with a car, } \\
\text { blocking the junction. }\end{array}$ & f. Move or run quickly. \\
$\begin{array}{l}\text { 7. The dog waited by the front door, } \\
\text { wagging its tail excitedly. }\end{array}$ & g. Hit gently into something. \\
\hline
\end{tabular}

\section{Challenge 6: Listening comprehension}

Students needed to listen to the song "Spinning over you" by Reiko and fill in the gaps with the following phrases:

My head is spinning over you I think I'm losing my defenses and when I'm standing next to you I feel the failure of my senses

You keep me locked under your spell I think I'm losing my direction and when I hear you say my name my body falls under sedation

And I'm trying and trying and trying and I'm trying God knows I'm trying and I'm trying to take you out of my mind My head is spinning over you Spinning over you

I'm getting shivers in my skin your voice is feeding my obsession and when you're standing close to me I feel I'm trapped in this temptation And I'm trying, and trying and trying and I'm trying God knows I'm trying

And I'm trying to take you out of my mind

My head is spinning over you

My head is spinning over you

And I'm trying, and trying and trying

and I'm trying God knows I'm trying

And I'm trying to take you out of my mind

\section{Results}

The game was successfully completed in the classroom and students responded to the activity with great enthusiasm and motivation. The results below show their answers to the above-mentioned questionnaire to analyse their perceptions and thoughts about the escape room.

First of all, $68.2 \%$ of students had never participated in an escape room in a classroom, and $90.9 \%$ of them said they had enjoyed taking part in it. One answer was neutral and one negative, with students reporting having felt frustrated during the game. However, other qualitative positive answers about the game were that it was "a very stimulating activity", "challenging", "different", "a difficult and fun way to learn English" or that the game "strengthened the relationship between partners". Regarding the skills they used the most, the following graph shows that speaking and reading were the most frequently used.

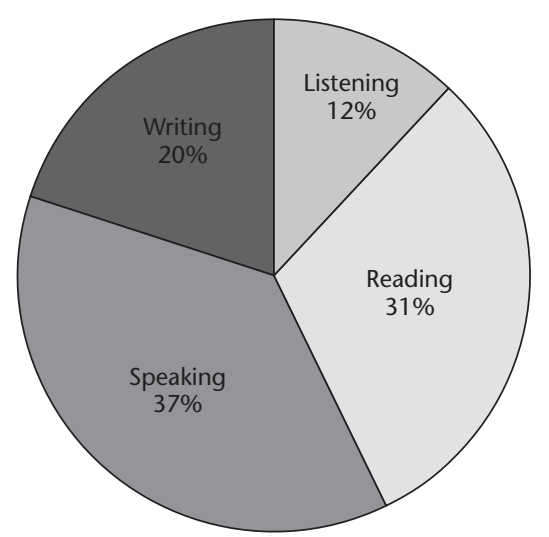

Figure 2. Most frequently used skills in the game

When asked if they thought the activity was effective for learning English, 95.4\% of students agreed that they found it effective. Some of the qualitative answers given in response to this question were the following:

Table 4. Qualitative answers about skills used

Qualitative answers

We practiced all the skills in a fun way.

For example, with the translation activity I used different expressions.

We did many different activities to practice different skills.

We did many different activities to practice different
It was a way to improve our English but in a fun way.

It was a way to improve our English but in a fun way.
It challenges you to complete the different clues and it also teaches you new things.

The same percentage of students (95.4\%) thought that this game was appropriate for using more English and less Spanish with their classmates compared to other group activities in the classroom. Some qualita- 
tive answers that students gave to support their opinions were the following:

Table 5. Qualitative answers about the effectiveness of the game for using English

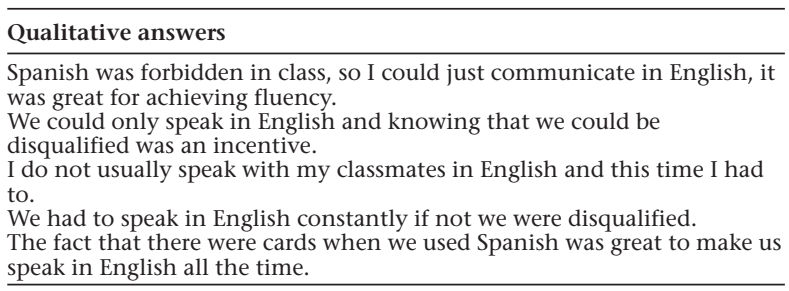

As for the activities they enjoyed the most, the following graph shows that the songs and translation activities were the most popular among students:

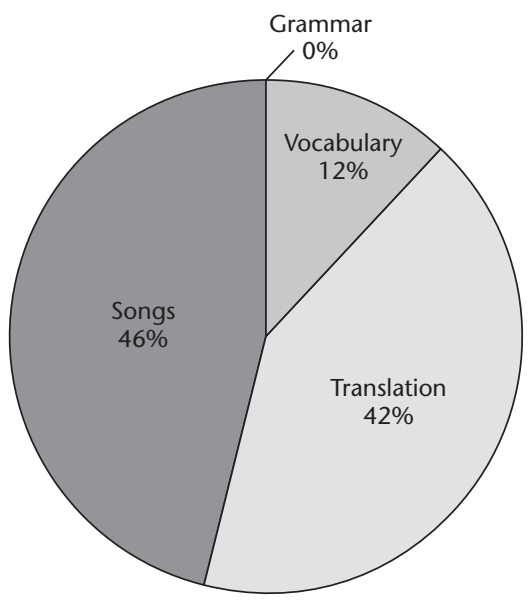

Figure 3. Most popular activities

The resources that they consulted during the game to solve the different challenges were mostly online dictionaries and databases.

On the other hand, students were given the following terms to choose from to describe the activity: enjoyable, learning, communication, authentic, relaxed, make friends, purposeful, cooperation, novelty and motivating. The following graph shows the frequency in which they were used:

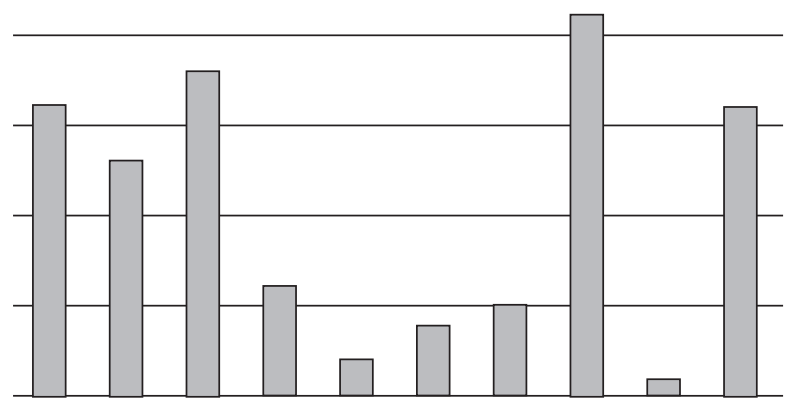

Figure 4. Most popular activities

As we can observe, the most popular terms were, from most to least popular, enjoyable, learning, communication, cooperation and motivating. This is in line with what our expectations, stated above, about the benefits that introducing games such as escape rooms to the classroom could have for students' learning experience, since it is a way to enhance their communicative skills as part of a team activity that makes them learn in an interactive and collaborative way.

Finally, students were given a number of items to answer on a Likert scale (Strongly agree, Agree, Neutral, Disagree, Strongly Disagree) (Table 6).

As we can observe, the game's level of difficulty challenged students' cognitive abilities in the classroom, since $45.4 \%$ of them neither agreed nor disagreed with the first statement, but $4.5 \%$ agreed and $9 \%$ strongly agreed. The same applies to the statement about the vocabulary used in the activities of the escape room. This is in accordance with the description of an ideal game offered above, as a classroom game should be neither so difficult as to become stressful nor so easy that that students become bored. The majority of them believed that the game had helped them acquire English skills and, more importantly, that they had learned more thanks to this game they would have with traditional activities or previous methods. Regarding students' feelings in the classroom, again the majority reported having felt more relaxed speaking in English with their classmates than they had during previous classroom activities. All in all, the game provided a cognitively demanding way of learning English, but in an appealing, cooperative and fun way.

\section{Discussion}

The purpose of this study was to present an innovative teaching proposal for the English as a second language classroom in a Translation Degree and to analyse the positive effects this activity could have on the students' learning experience. As shown in the results section, the majority of students displayed positive attitudes towards the use of the escape room as a gamification experience in the classroom, and they reported having learnt more, and in a more effective way, than they would have with traditional methods. This experience has proved effective way at enhancing students' interest and motivation in the class and at activating a range of additional language learning skills in an interactive, cooperative context that facilitates the students' learning process in a more enjoyable and meaningful way.

In future research, we believe that more emphasis should be placed on gamifying grammar activities, since this remains one of the aspects of language learning that students enjoy the least. Moreover, this gamification technique can be applied to other classes, such in the as specialized translation classroom, in order to compare and contrast results and continue to improve. Another possible modification of this escape room would be to adapt it to our digitally native students and create an online escape room, an activity that could then be carried out anywhere and at any time, which would give immediate feedback to the participants. Furthermore, cooperation between stu- 
Table 6. Statements about the escape room

\begin{tabular}{|c|c|c|c|c|c|}
\hline Statement & Strongly disagree & Disagree & Neutral & Agree & Strongly agree \\
\hline The game was too difficult & $4.5 \%$ & $36.6 \%$ & $45.4 \%$ & $4.5 \%$ & $9 \%$ \\
\hline It was fun to play the game & & $9 \%$ & & $54 \%$ & $37 \%$ \\
\hline The vocabulary in the game was difficult & $9 \%$ & $18.2 \%$ & $54.5 \%$ & $18.3 \%$ & \\
\hline I think this game helped me acquire English skills & & & $18.2 \%$ & $54.5 \%$ & $27.3 \%$ \\
\hline $\begin{array}{l}\text { I think I could learn more English with this method than with } \\
\text { traditional methods }\end{array}$ & & $13.6 \%$ & $13.6 \%$ & $40.9 \%$ & $31.9 \%$ \\
\hline $\begin{array}{l}\text { I spoke more in English during the development of this game } \\
\text { than with previous methods }\end{array}$ & & & $4.5 \%$ & $41.5 \%$ & $54 \%$ \\
\hline $\begin{array}{l}\text { I could learn more vocabulary with this game than from a } \\
\text { textbook or with previous methods }\end{array}$ & & & $31.8 \%$ & $45.5 \%$ & $22.7 \%$ \\
\hline $\begin{array}{l}\text { I could learn more English grammar with this game than from a } \\
\text { textbook or with previous methods }\end{array}$ & & $9 \%$ & $31.8 \%$ & $41 \%$ & $18.2 \%$ \\
\hline $\begin{array}{l}\text { I felt more relaxed interacting in English with my classmates } \\
\text { during the game than during previous activities }\end{array}$ & $4.5 \%$ & $9 \%$ & $22.7 \%$ & $45.6 \%$ & $18.2 \%$ \\
\hline
\end{tabular}

dents would be enhanced, as they would work together online, despite not sharing a common space as they did in this study. The potential variations of escape room would not only offer a more enriching learning experience in different formats, but would represent a different approach to the second language learning, a way to escape the traditional classroom and enter a world of possibilities, motivation, cooperation, learning and enjoyment. With these in mind, why wouldn't you want to escape?

\section{References}

Akçayır, M., Dündar, H., \& Akçayır, G. (2016). What makes you a digital native? Is it enough to be born after 1980? Computers in Human Behavior, 60, 435440. https://doi.org/10.1016/j.chb.2016.02.089

Apostol S., Zaharescu L. \& Alexe I. (2013). Gamification of Learning and Educational Games. $9^{\text {th }}$ International Scientifc Conference eLearning and software for Education, Bucharest, 67-72.

Alcalde, E., \& Santamaria, A. (2018). Tweets of a Feather Flock Together: An Analysis of the Impact of Twitter in a Class of Translation. International Journal of Virtual and Personal Learning Environments (IJVPLE), 8(2), 10-23.

Castellón, L. \& Jaramillo, O. (2012). Educación y videojuegos: hacia un aprendizaje inmersito. Barcelona: Homo Videoludens.

Cebrián, M. (2011). Los centros educativos en la sociedad de la información y el conocimiento. In Cebrián, M. \& Gallego M. J., Procesos educativos con TIC en la sociedad del conocimiento (p.23-31). Madrid: Pirámide.

Chen, W. (2015). What is an escape room game? Retrieved from https://www.quora.com/What-is-anescape-room-game

Clanfield, L. \& Jeffries, A. (2016). Global. Madrid: Macmillan.

De Sousa Borges, S., Durelli V.H.S., Macedo Reis H., \& Isotani S. (2014). A Systematic Mapping on Gamification Applied to Education. Proceedings of the 29th Annual ACM Symposium on Applied Computing, 216222.

Deterding, S., Dixon, D. Khaled, R. \& Nacke, L. (2011). From Game Design Elements to Gamefulness: Defi- ning 'Gamification. In Proceedings of the 15th International Academic MindTrek Conference: Envisioning Future Media Environments, 9-15.

Dicheva, D., Dichev, C., Agre, G., \& Angelova, G. (2015). Gamification in education: A systematic mapping study. Educational Technology \& Society, 18(3), 75-88.

Dignan, A. (2011). Game Frame: Using Games as a Strategy for Success. New York: Free Press, New York.

Dimitrios, N. K. \& Niemann, S. (2017). Gamification and Game-based learning. Journal of Educational Technology Systems, 45(4), 499-519. https://doi. org/10.1177/0047239516665105

Faiella, F. \& Ricciardi, M. (2015). Gamification and Learning: A Review of Issues and Research. Journal of e-learning and language society, 11(3), 13-21.

Feng Liu, E. Z. \& Chen, P. (2013). The Effect of GameBased Learning on Students' Learning Performance in Science Learning - A Case of "Conveyance Go". Procedia - Social and Behavioral Sciences, 103, 1044-1051.

Ferrara, J. (2012). Playful Design. Creating Game Experiences in Everyday Interfaces. New York: Rosenfeld Media.

Figueroa Flores, J.F. (2015). Using Gamification to Enhance Second Language Learning. Digital Education Review, 27, 32-54. Universitat de Barcelona.

Foncubierta, J. M. \& Rodríguez, C. (2014). Didáctica de la gamificación en la clase de ELE. Madrid: Edinumen.

Gisbert Cervera, M. \& Esteve Mon, F. M. (2011). El nuevo paradigma de aprendizaje y las nuevas tecnologías. Revista de docencia universitaria, 9, 55-73.

González Daviès, M. (2004). Multiple Voices in the Translation Classroom. Benjamins Translation Library.

González-Davies, M. (2017). The use of translation in an integrated plurilingual approach to language learning: Teacher strategies and best practices. Journal of Spanish Language Teaching, 4(2), 124-135. https:// doi.org/10.1080/23247797.2017.1407168

Grace, M.V. \& Hall, J. (2008). Projecting Surveillance Entertainment. Presentation, ETech, San Diego, CA.

Haskell, C. (2013). Understanding Quest-Based Learning: Creating effective classroom experiences through game-based mechanisms and community. Retrieved from http://gogolabs.net/wp-content/ uploads/2013/01/QBL-Whitepaper_Haskell-final.pdf 
Huang, L. \& Yeh, Y. (2017). Meaningful Gamification for Journalism Students to Enhance Their Critical Thinking Skills. International Journal of Game-Based Learning (IJGBL), 7 (2).

Hubscher-Davidson, S. \& Borodo, M. (2012). Global Trends in Translator and Interpreter Training. New York: Continuum.

Kapp, K. M. (2012). The gamification of learning and instruction: game-based methods and strategies for training and education. United States of America: Pfiffer.

Kasa, N. (2018). Is stress damaging your health? Retrieved from http://kensingtonnutrition.co.uk/stressdamaging-health/

Kiryakova, G., Angelova, N., \& Yordanova, L. (2014). Gamification in education, Proceedings of 9th International Balkan Education and Science Conference. Retrieved from https://www.sun.ac.za/english/learning-teaching/ctl/Documents/Gamification\%20 in\%20education.pdf

Liu, E. Z. F. (2011). Avoiding internet addiction when integrating digital games into teaching. Social Behavior and Personality, 39(10), 1325-1336.

Clandfield, L., Jeffries, A., Robb, R. \& Vince, M. (2016). Global Advanced Coursebook. Madrid: MacMillan.

Malmkjaer, K. (2004). Translation in Undergraduate Programmes. John Benjamins Translation Library.

Marczewski, A. (2012). Gamification: A Simple Introduction, Raleigh, Lulu.

Martínez Sánchez, F. \& Sánchez Vera, M.M. (2011). Diseño de procesos y materiales de enseñanza con TIC para infantil y primaria (pizarra digital y objetivos de aprendizaje). In M. Cebrián De la Serna \& M.J. Gallego Arrufat (Eds.), Procesos educativos con TIC en la sociedad del conocimiento (pp. 121-135). Madrid: Pirámide,

McDonald, M., (2008). Using Productivity Games to Prevent Defects. In M. McDonald, R. Musson, and R. Smith (Eds), The Practical Guide to Defect Prevention (pp. 79-95). Microsoft Press, Redmond.

Moreno Martínez, N. Leiva Olivencia, J.J. \& Matas Terrón, A. (2016). Mobile learning, gamificación y realidad aumentada para la enseñanza-aprendizaje de idiomas. International Journal of Educational Research and Innovation, 6, 16-34.

New Media Consortium. (2014). Horizon Report on Technology and Higher Education. Retrieved on March 3, 2015 from http://www.nmc.org/publication/nmchorizon-report-2014-highereducation-edition/
Perrotta C., Featherstone G., Aston H., \& Houghton E. (2013), Game-based Learning: Latest Evidence and Future Directions, Slough, NFER.

Prensky, M. (2001). Digital natives, digital immigrants part 1. On the horizon, 9(5), 1-6.

Prensky, M. (2005). Listen to the natives. Vancouver: Educational Leadership.

Rizzo, C. (2018). Escape rooms: una herramienta útil para que las empresas analicen a sus trabajadores. Retrieved from: https://www.20minutos.es/noticia/3232586/0/escape-rooms-herramienta-empresasanalizar-trabajadores/

Ružić, I.M. \& Dumančić, M. (2014). Gamification in education. Informatol, 48, 198-204.

Salen, K. \& Zimmerman, E. (2004). Rules of play: game design fundamentals. Massachusetts: MIT Press.

Simões J., Díaz Redondo R., \& Vilas A.F. (2013). A social gamification framework for a K-6 learning platform. Computers in Human Behavior, 29, 345-35. https://doi. org/10.1016/j.chb.2012.06.007

Sharp, J. G., Brian Hemmings, Russell Kay, Barbara Murphy \& Sam Elliott (2016). Academic boredom among students in higher education: A mixedmethods exploration of characteristics, contributors and consequences. Journal of Further and Higher Education, 41(5), 657-677.

Takahashi, D. (2008). Funware's threat to the traditional video game industry. Retrieved from https:// venturebeat.com/2008/05/09/funwares-threat-tothe-traditional-video-game-industry/

Thorne, S. L., \& Watters, E. (2013). Review of Language at Play: Digital Games in Second and Foreign Language. Teaching and Learning. Language Learning \& Technology, 17(3), 47-51.

Universidad de Alcalá (2017). Syllabus of the English 2 course. Retrieved from: http://www.uah.es/export/ sites/uah/es/estudios/estudios-oficiales/grados/.galleries/Programas/G791/251009_G791_2017-18.pdf

Wlodkowski, R. \& Ginsberg, M.B (2017). Enhancing Adult Motivation to Learn: A Comprehensive Guide for Teaching All Adults. John Wiley \& Sons.

York, J. \& William, J. (2018). A Constructivist Approach to Game-Based Language Learning: Student perceptions in a Beginner Level EFL Context. International Journal of Game-Based Learning, 8(1), 19-40. DOI: 10.4018/IJGBL.2018010102 